\title{
ENVIRONMENTAL CHANGES, RURAL OUT-MIGRATION AND SOCIAL DYNAMICS IN HIMALAYAS
}

\author{
Prakash C. TIWARI ${ }^{1} \bullet$ Bhagwati JOSHI $^{2}$ \\ ${ }^{1}$ Kumaon University \\ Nainital - 263002, Uttarkhand, India \\ pctiwari@yahoo.com \\ ${ }^{2}$ Government Post Graduate College \\ Rudrapur, Uttarakhand, India \\ bhawanatiwari@yahoo.com
}

\begin{abstract}
The paper aims at interpreting inter-linkages between environmental changes and rural out-migration and at assessing their impacts on quality of life of rural women with a case illustration of Upper Kosi Catchment, Uttarakhand Himalayas, India. The results indicate that the availability of water, fuel-wood and fodder decreased, agricultural production declined and livelihood opportunities were reduced mainly due to depletion of natural resources. Consequently, the male out-migration increased by 15\% during 1981-2011. This increased workload of women by $25 \%$, more than $40 \%$ women are under severe threat of a variety of health risks generated mainly due to excess work-load, under-nourishment and lack of hygiene and sanitation.
\end{abstract}

Key-words: Primary resource developers, ecosystem services, climate change, food and livelihood security, sanitation and health, sustainable development, India, Himalayas.

\section{Introduction}

In the Himalayas, due to constraints of terrain and climate, subsistence agriculture constitutes the main source of rural livelihood even though the availability of arable land is severely limited and agricultural productivity is low (ICIMOD 2010). Due to the limitations of subsistence economy, a large proportion of adult male population out-migrates from the region in search of livelihood (Maithani 1996). This phenomenon of exodus of young and able-bodied human resource from the mountains has serious implications not only for economic development, but also for the enrichment of socio-cultural life in the region. This led to feminisation of agriculture and livelihood in the Himalayas (ICIMOD 2010). Consequently, the women of the Himalayas have been often designated as 'primary resource developers', and the burden of living under difficult mountain-conditions falls mainly on women who have to bear the drudgery of scrounging for all primary natural resources including collection of fuel-wood and fodder from shrinking forests, fetching water from increasingly long distances besides taking care of agriculture, livestock, children and aged 
members of the family (Maithani 1996). On the other hand, there is severe shortage of adult male labour to work in agriculture and other sectors of rural economy which further acts as a drag on agricultural productivity and retards the process of socio-economic development in the mountains. The cumulative impact of all these physical, socio-economic and cultural constraints in the mountains is leading to grinding poverty, hardship, constant fear of insecurity, a feeling of helplessness, and complete dependence on the outside help. The environment thus created is not conducive to attaining the goals of sustainable mountain development (Maithani 1996; Joshi and Tiwari 2013).

During the recent past a variety of changes has emerged in traditional resource utilization pattern mainly in response to the population growth and resultant increased demand of natural resources, and to the global change, particularly economic globalisation, urbanization and climate change in the Himalayas (IOM 2008; Jain and Nagarwalla 2004; Tiwari and Joshi 2012a). Women experience these changes differently and disproportionately and respond to them in a varying manner because of socially constructed gender relations and environmental sensitivity of mountain ecosystems. They make use of their critical traditional knowledge of and experience with natural resource management and adapting agricultural and food systems to multiple drivers of environmental change, including climate change, globalisation and economic processes, out-migration, and land-use changes in mountain environments, which helped women to become an important agent of sustainable mountain development (ICIMOD 2011). However, these changes have exerted sharply accentuated pressures on local economy through depletion of land, water, biodiversity and forests resources, collapsing conventional production system and increasing community vulnerability to livelihood and food insecurity and increased risks of natural disasters (World Bank 2009; Lonergan 1998). This has augmented male out-migration, and consequently increased hardships of rural women and deteriorated their quality of life (Mamgain 2003; Tiwari and Joshi 2012b).

\section{Conceptual Background}

Mountains have long been marginalized from the view point of sustainable development of their resources and inhabitants. However, during the recent years our understanding about the problems of mountain regions and approach to their development has undergone drastic changes (ICIMOD 2010). This is reflected by a deepening anxiety over the depletion of natural resources and disruption of mountain ecosystem services. As a result, the significance of mountain social-ecological systems was acknowledged for the first time on a global scale in Agenda 21 of the United Nations Conference on Environment and Development (UNCED), held in Rio de Janeiro, Brazil, in 1992 (UN 2012). Mountains include some of the most fragile ecosystems on the planet (ICIMOD 2010) as they are highly sensitive to changes caused by natural as well as anthropogenic factors (Sonesson and Messerli 2002). The drivers of changes range from a variety on natural hazards and disasters to a series of human-induced processes such as population growth, depletion of natural resources, urbanization, economic globalisation and resultant intensification of land use (Tiwari 2000; ICIMOD 2011). Moreover, changing climatic conditions have put pressure on the mountain environments through higher mean annual temperatures and melting of glaciers and snow, altered precipitation patterns, and more frequent and extreme weather events 
which are likely to intensify the impacts of other natural as well as socio-economic drivers of change (IPCC 2007; UNEP-WCMC 2002; CIDA 2002; Brody et al. 2008; Daley 2011).

Subsistence agriculture, livestock raising and income generation through small scale trade, and wage and casual labour constitute the main source of livelihood of mountain communities (Leduc and Shrestha 2008). The Food and Agricultural Organization (FAO) of the United Nations has identified more than $75 \%$ of the land surface of the world's mountain as unsuitable or marginally suitable for agriculture (Huddleston and Ataman 2003; Messerli and Ives 1997; IFAD 2001). It has been observed that the proportion of poor and vulnerable people increases with elevation (Huddleston and Ataman 2003). There are indications that poverty inequality between mountain people and those living in other areas is currently increasing (ICIMOD 2010). Approximately, 271 million people, which accounts for nearly $40 \%$ of the mountain population in developing and transition countries, have been estimated to be highly vulnerable to food insecurity, specifically in Asia and Latin America (Huddleston and Ataman 2003; FAO 2008). High dependency on natural resources and increasing marginalisation are some of important factors for prevailing poverty, food and livelihood insecurity and poor community health, in mountains of developing countries which are further increasing their vulnerability to long-term impacts of global environmental changes (Huddleston and Ataman 2003). The globalizing economy has both positive as well as negative impacts on the mountain livelihoods and economy. The fast growing tourism industry in India, China and Nepal has opened new opportunities for the growth of mountain economy. Furthermore, China and India are the fastest growing economies in Asia, yet, they have the highest poverty ratios. Moreover, the economic globalisation have further increased the vulnerability of the mountain communities to the environmental risks through exploitation of natural resources even in remote and inaccessible areas, particularly in the developing countries. This seems to have further deepened poverty imbalances between highlands and lowlands (Hassan et al. 2005; Huddleston and Ataman 2003).

However, for millennia the mountain communities were developing distinctive mechanisms to adapt to these typical conditions through evolving a range of adaptive measures (UNEP 2004; ICIMOD 2010). Migration of male youth is one the important adaptive measures to constraints of subsistence economy and changing environmental conditions and associated natural and socio-economic risks across all the mountain regions of the world (Sherpa 2007). On one hand, labour migration improves economic conditions and ensures food security in terms of remittance (Kollmair et al. 2006); on the other hand, it has inadvertently created a vacuum in the mountain societies, putting extra responsibilities on women (Sherpa 2007). During 1991-2000, the level of adult male out-migration in the mountainous regions of South Asia exceeded 40\% (Rasmussen and Parvez 2002). Draining away of productive human resource from mountains has serious implications not only for the economic development, but also for the enrichment of socio-cultural life in the region (Maithani 1996). Women, being natural resource developers, possess undocumented indigenous knowledge, and their contribution towards preserving the mountain cultures and natural resources is highly significant (ICIMOD 1999). However, the depletion of natural resource base has affected women adversely by increasing their workload and marginality (UNDP 2010).

As a result, women play crucial role in mountain societies as major work force in food production system and as key players in the conservation and management of natural re- 
sources and environments (FAO 2010, 2011). Globally, women share is nearly $43 \%$ of the work force in agricultural sector, and mountain regions of Asia, Africa, and Latin America it is above 50\% (Sherpa 2007). The combined hardship and adversity of mountain living conditions trained the women to respond radically to the forces that were exploiting their natural resources and undermining their livelihoods. Rural women's active participation in the conservation and management of their natural resources laid the foundation for the well known environmental movements in the seventies (Verma 2001). The famous 'Chipko Movement' (hugging the trees movement) of Uttarakhand - a distinctly non-violent grassroots movement - was organized and lead by illiterate rural women against the exploitative state forestry policy in 1970s. However, women in the Himalayas are particularly vulnerable to the impacts of environmental changes due to skewed power relations and inequitable cultural and social norms, as a result, they are often disadvantaged in terms of power relations and accessing resources, and exposed to increased risks associated with environmental changes (ICIMOD 2010). These risks include further marginalization, exclusion from decision-making and dislocation from access to resources for survival. Women generally have far less access to and control over the resources they manage and conserve (Sherpa 2007). The women of the Hindu Kush Himalayas of Afghanistan, Bangladesh, Bhutan, China, India, Myanmar, Nepal and Pakistan share almost similar status; however there are variations in the level of the status due to cultural and social disparities (ICIMOD 1999; Sherpa 2007).

With this in view, the feminists, particularly those from Latin American and South Asian countries, started a movement for women's equality in 1980s, and this lead to the concept of women's empowerment in the South (Stromquist 2002). This challenged not only patriarchy, but also the mediating structures of class, race, ethnicity; and in case of India, caste and religion, and empowerment was considered as a socio-political process that required shifts in political, social, and economic power between and across both individuals and social groups (Batliwala 2007). In the following decade, empowerment had emerged as one of the important components of development discussion and was widely used with reference to women and gender equality by the national and international agencies (Malhotra and Schuler 2005). Since then, a series of developmental programmes have been conceived, formulated and implemented from global to national and local levels for the social, economic and political empowerment of women in developing and less developed countries including India. Nevertheless, the mountain women are not only deprived of the facilities necessary for a good quality of life, but they often remain uninvolved in the development process as well (Nautiyal 2003). As a result, development has failed to bring about significant changes in the quality of life of women, particularly in the remote Himalayan mountains, and women's access to minimum quality of life still remains at a very low level which is in fact reinforcing the feminisation of poverty (Sherpa 2007).

\section{Objective}

Besides interpreting the inter-linkages between environmental changes and rural out-migration, the study also aims to explore their impacts on quality of life of rural women with a case illustration of Uttarakhand Himalayas, India. 


\section{Research Methodology}

The Study Area: The Upper Kosi Catchment which encompasses land surface area of $107.94 \mathrm{~km}^{2}$ (10,794 ha) between elevations of 1,425 $\mathrm{m}$ and 2,650 $\mathrm{m}$ above mean sea level in the Lesser Himalayan ranges of the State of Uttarakhand in India (Fig. 1) has been taken as the area of study in the present work. The Upper Kosi Catchment also constitutes the 'headwater' of river Kosi. The total population of the region amounts to 16,080 persons who live in 62 villages. The watershed is one of the most densely populated and agriculturally intensive areas of Kumaon with an average population of 149 persons $/ \mathrm{km}^{2}$, rising to 469 persons $/ \mathrm{km}^{2}$ for villages. The major land use categories are forests, cultivated land and barren land. Subsistence agriculture with animal husbandry as its natural ally constitutes the main source of livelihoods for more than $75 \%$ of the population, although the availability of arable land is severely limited. More than $90 \%$ of operational land holdings are less than one hectare in size, and the availability of cultivated land is only 0.17 ha per capita, resulting in low agricultural productivity as well as low economic viability of agriculture in the region. Consequently, a large proportion of adult male population out-migrate in the region. Despite increasing trend of out-migration, the community has shown rapid but unsustainable growth, putting increased stress on land, forests, water and other critical natural resources of the region. Cultivation, grazing and deforestation have been extended over large areas leading to ecological instability and food insecurity in the entire river basin. The entire Upper Kosi Catchment has been divided up into four micro-watersheds for comprehensive study of various research parameters included in the study.
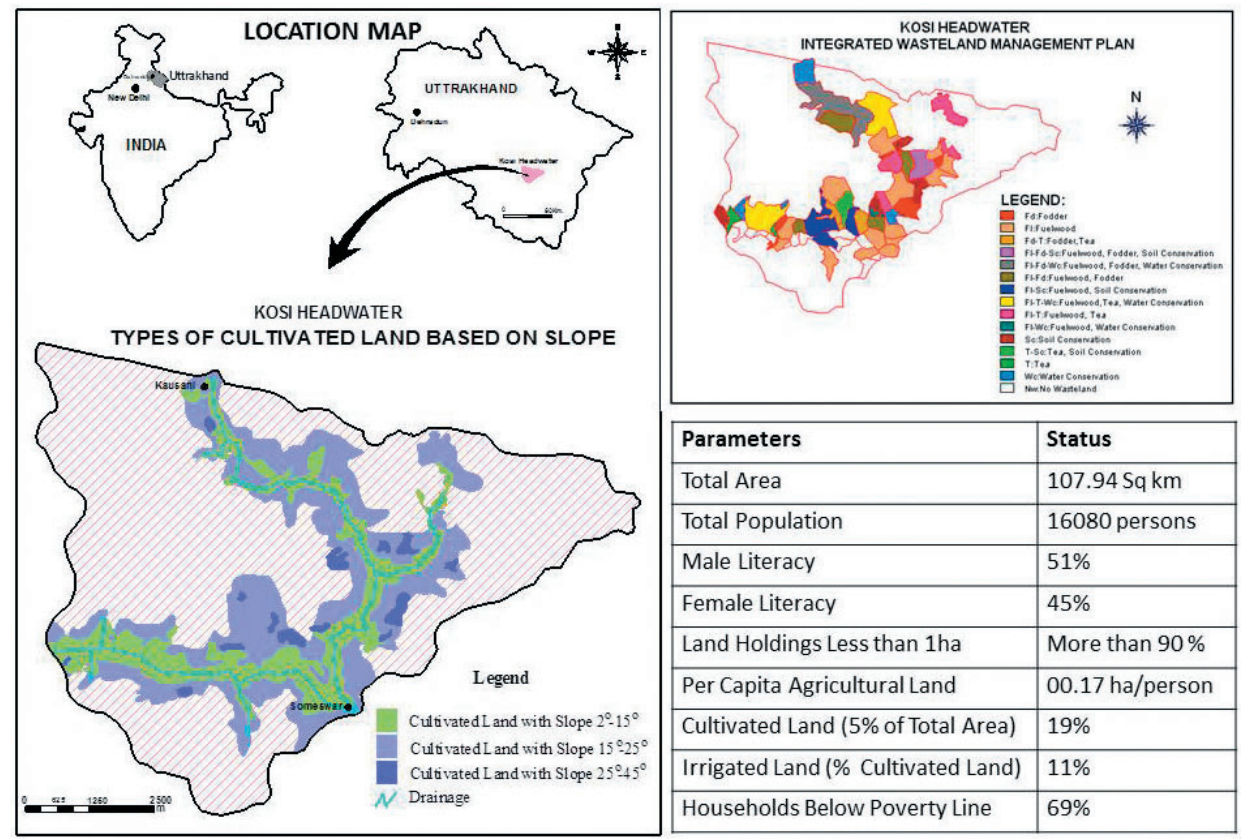

Fig. 1. Upper Kosi Catchment - Location and Socio-cultural Profile 
Materials and Methods: Methodology included the following: (a) appraisal of land, water and forest resources based on digital interpretation of multi-date satellite data supported by the ground validation; and (b) generation and analysis of primary socio-economic data for: (I) identification of factors of resource utilization dynamics and environmental changes; (II) interpretation of inter-linkages between resource depletion, local production systems, traditional livelihood and women, and (III) analysis of the impact of depleting natural resource base on the conventional rural livelihood, and appraisal of its effect on rural out-migration and the status and quality of life of women. The information and data required for the study have been generated and collected from varying sources. The primary information has been generated through intensive field surveys and mapping, observations, monitoring, and socio-economic surveys. The secondary methods mainly included the interpretation of high resolution satellite data. Besides, the necessary data and information required for the study have also been collected from the Survey of India (SOI) topographical maps of the area at scale 1:50,000, forest maps, cadastral maps and other records. Panchromatic (PAN) and Linear Imaging Self Scanner (LISS-3) merged data (5.8 $\mathrm{m}$ resolution ) of the Indian Remote Sensing Satellite 1D (IRS-1D) and Cartosat-2 data (with $1 \mathrm{~m}$ spatial resolution) were used for the survey and mapping and appraisal of land, water and forest resources and interpretation of their dynamics. Digital interpretation techniques supported by intensive ground validation have been used for this purpose. The interpretation of satellite data was followed by an intensive reconnaissance survey to get acquainted with the general pattern of land use of the study area (Fig. 2). In order to analyse the resource use dynamics and resultant environmental changes the land use maps were prepared for the years 2001 and 2011 using PAN and LISS-3 and Cartosat-2 data, respectively (Fig. 2). Finally, these land use maps have been converted into spatial layers and crossed with each other using GRAM++ GIS Software package developed by the Centre of Studies in Resources Engineering (CSRE), Indian Institute of Technology (IIT), Mumbai (Fig. 2).

The information pertaining to out-migration was collected from Village Register of each of the 62 villages of the catchment. In order to develop the estimates of production and demand for natural resources the comprehensive socio-economic surveys were conducted using exclusively designed village and household schedules. General information about forest, agricultural land and water resources have been collected from each of the 62 villages using village schedule by interviewing the head and members of Village Council. The information with respect to production and demand of food, fuel-wood and fodder; issues associated with increasing trends of out-migration; and factors leading to transformation of community resource utilization structure and depletion of natural resources and their impact on traditional rural livelihood, resource collection distances, work load on women, community health, water availability and utilization, food consumption pattern, and impact of natural disasters was generated through household surveys conducted in all the villages. The sample size covered 33\% of the total households (out of total 2197 households) selecting respectively women headed households (25\%), households below poverty line (as classified by the Government of Uttarakhand State) (40\%), households solely dependent on agriculture (15\%) and families dependent of agriculture and other means of income (20\%). The resource deficit, sufficiency and surplus situations with respect to food, fodder and firewood have been determined by identifying the gaps between production and demand (Fig. 3). The environmental status of water resources 


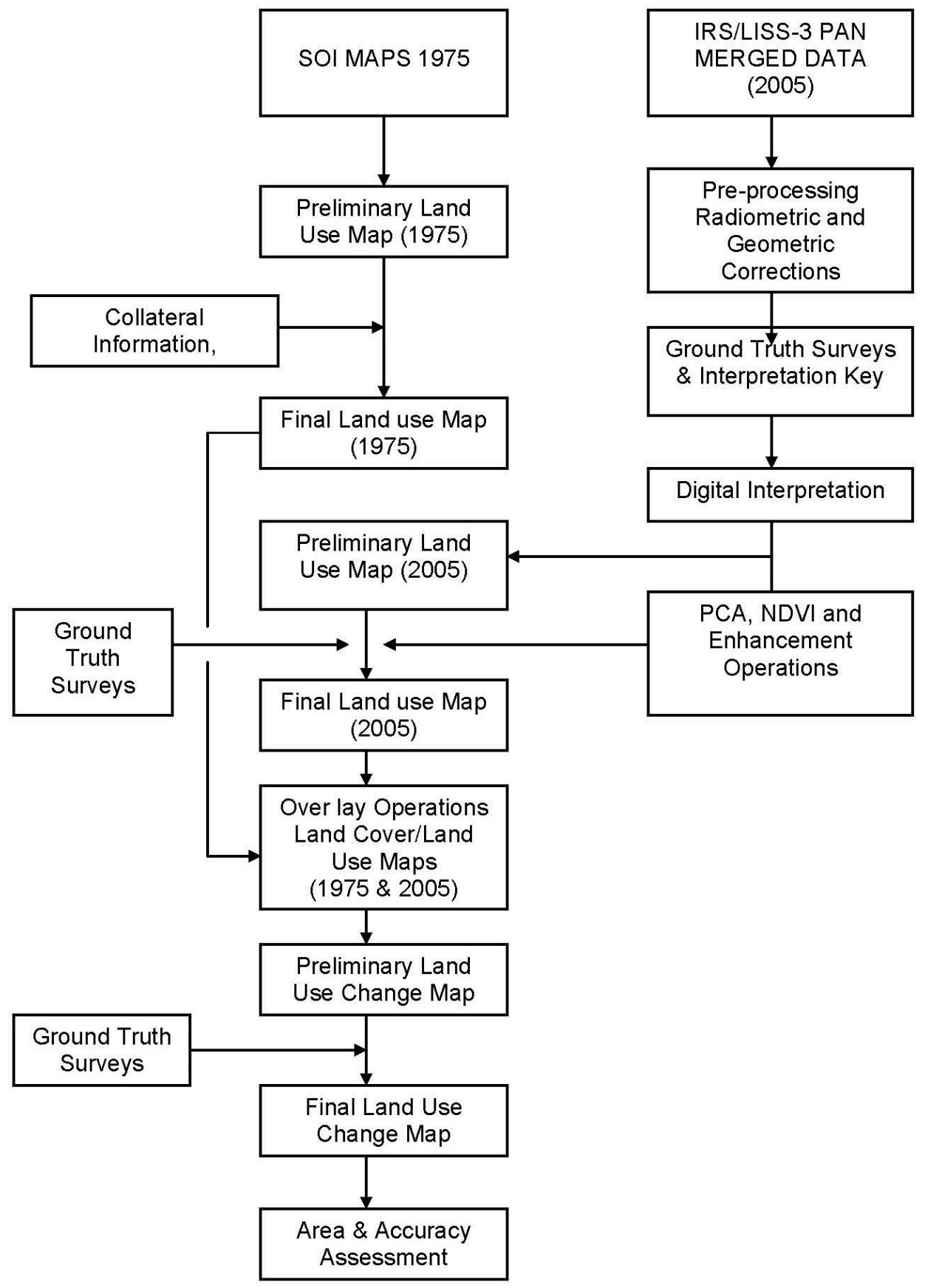

Fig. 2. Methodology for Land Use Change Detection 
(streams and springs) has been determined through intensive field surveys, mapping, and interviewing elderly people in the each of the villages of the study region. The travel distances covered to fetch water, firewood and fodder have been calculated by interviewing people in all the villages of the region and then computing the average distance of each village.

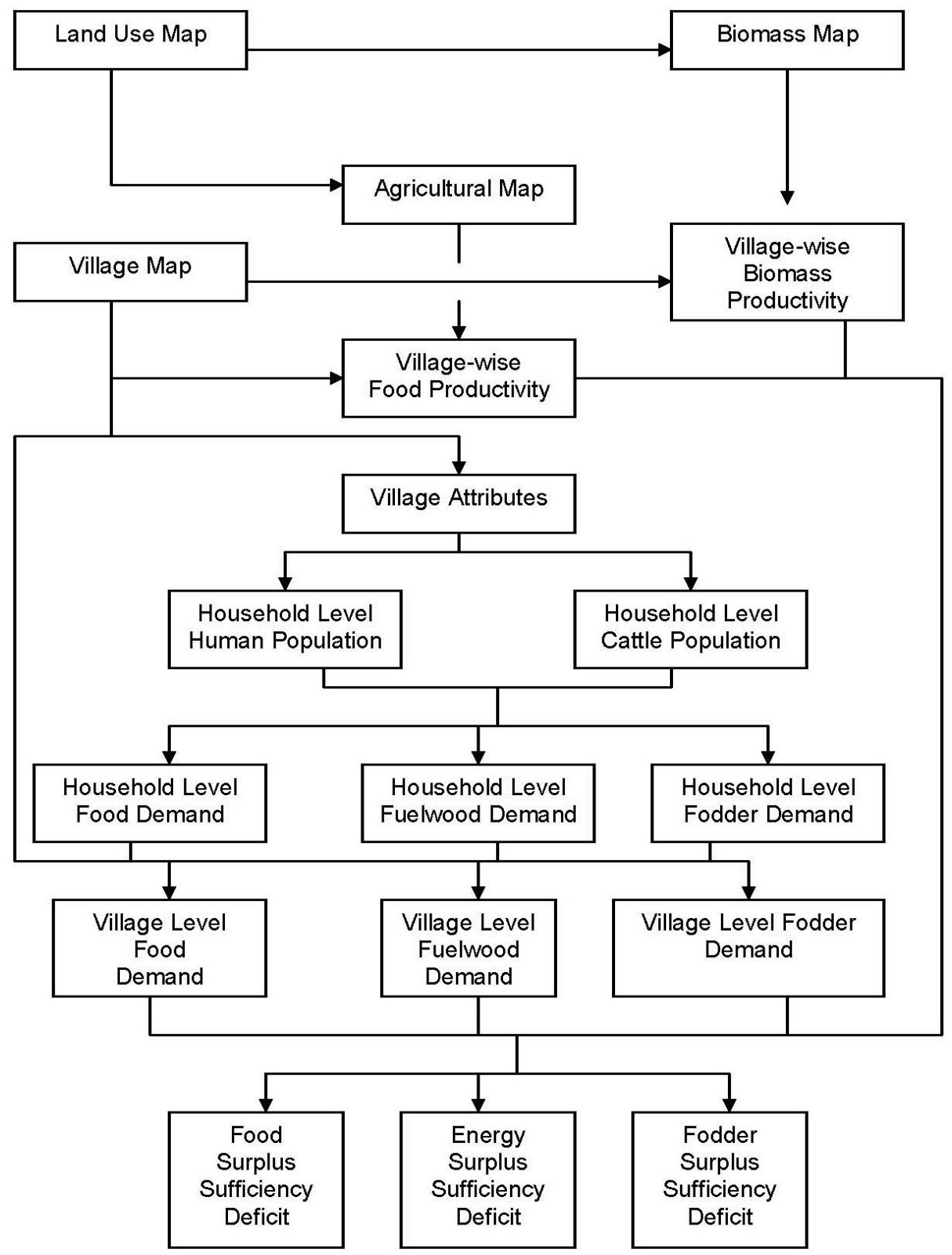

Fig. 3. Methodology for Resources Efficiency Analysis 


\section{Results and Discussion}

\section{Traditional Agricultural and Food System}

As in other parts of the Himalayas, due to constraints of terrain and climate more than $75 \%$ population of the region is dependent on traditional subsistence agriculture for its food and livelihood. However, crop farming is not economically viable in most areas of the region due to several geo-environmental constraints and resultant poor agricultural productivity. The availability of arable land is considerable low and size of land holdings is very small. In order to preserve soil fertility level and productivity of land under sustained cropping, the biomass energy from adjoining forests, grasslands and pastures is transferred to cultivated land and this flow of energy is mediated through livestock-population in the form of compost manure and labour to the cultivated land. Therefore, the forests, livestock and agricultural land are the three core components of the Himalayan agro-ecosystem in which the forests are pivotal for the maintenance of agricultural production. It has been estimated that one unit of agricultural production involves on an average nine units of energy from the surrounding forest, grasslands and pastures in conventional Himalayan agricultural system (Singh et al. 1884).

The livelihood and food security in the Himalayas depends mainly on local agricultural production, and the food purchasing capacity of households which in turn is determined by opportunities of local employment and remittances coming from migrated population (Aase et al. 2013; Tiwari and Joshi 2012a). Therefore, the region is likely to face food insecurity in near future as there are clear indications that the agricultural production has declined by nearly $25 \%$, leading to a food deficit of approximately $65 \%$ (from local agricultural production) over the last 30 years (Tiwari and Joshi 2012b). This has been mainly due to depletion of critical agricultural resources, such as land, water and forest and climate change (particularly changes in precipitation pattern) and resultant decline in agricultural productivity (Tiwari and Joshi 2012a, b). Furthermore, it would be difficult to fill up the food deficit gap in the near future as the purchasing power of local people has declined due to loss of local livelihood opportunities in traditional forestry and agricultural sectors (Tiwari and Joshi 2012b). Due to constraints of subsistence economy the intensity of cropping is as high as 168\% (Pant 2000), and a large proportion of rural youth-male population out-migrates of the region in search of livelihood (Hoermann and Kollmair 2009; Tiwari and Joshi 2012b). This is expected to have long-term impact on the food security in the region in terms of both availability of and access to food which will particularly affect the poor and socially marginalized people who constitute nearly $75 \%$ of the total population. This will have serious implications for fundamental welfare-programmes ranging from poverty-alleviation to climate change adaptation in the region and will affect particularly the rural women.

Traditional resource utilization pattern in the region has been changing fast mainly in response to population growth (average more than 1.5 percent/year) and an increasing economic and social marginalization (Tiwari and Joshi 2012a, b). The impacts of changes in community resource utilization structure are clearly discernible in terms of the intensification of land use and the resultant environmental changes (Tiwari 2000). Agriculture is being extended to forests and marginal and sub-marginal lands, and pastures are turning into waste and degraded land due to overexploitation and resultant decline in productivity. With a rapid growth of population the pressure on cultivated land has increased, 
and consequently, the per capita availability of cultivated land is merely $0.17 \mathrm{ha} /$ person against a minimum of $0.2 \mathrm{ha} /$ person as required for practicing agriculture on sustainable basis in high Himalayan mountain ecosystem (Ashish 1983). These changes in traditional resource utilization structure are not only leading to rapid environmental changes and disruption of ecosystem services but also contribute to the climate change through the deforestation and degradation of forests in Himalayas (Tiwari and Joshi 2012a, b).

\section{Impact of Environmental Changes on Ecosystem Services}

Ecosystems are natural assets that provide a wide range of services and products which sustain humanity across the planet (Millennium Ecosystem Assessment 2005). The mountains support a variety of ecosystems that provide key resources and services for human sustenance (Beniston 2005). For example the mountain communities have contributed significantly to the conservation and protection of these ecosystem goods and services with their indigenous knowledge and traditional resource management practices. The goods and services provided by mountain ecosystems can be divided into the following three primary categories (Hassan et al. 2005; UNEP-WCMC 2002): (I) Supporting Services which maintain the essential natural conditions for all forms of life and include soil formation, photosynthesis and nutrient cycling; (II) Provisioning Services that provide means of livelihoods and the economy by supplying various natural resources and products, such as food, water, timber, and fibre. Undoubtedly, the most important good provided by mountain ecosystem is water and, therefore, the mountains are often known as 'water towers' for the world (ICIMOD 2011). Nearly 85\% of global freshwater comes from the mountains (Viviroli et al. 2003; Nellemann et al. 2011); (III) Regulating Services contribute to the control of climate, flood and disease, while maintaining water quality and recycling wastes; and (IV) Cultural Services provide opportunities for recreation, education and spiritual and aesthetic inspiration (World Resource Institute 2005).

The results of land use change detection exercise in GIS environment have revealed that cultivated land was extended from $24.29 \mathrm{~km}^{2}$ in 2001 to $27.27 \mathrm{~km}^{2}$ in 2011 . This extension of cultivated land has been obtained mainly through penetration of agriculture into the forests. This increase in the cultivated land area has been through the extension of cultivation in the forests $\left(3.34 \mathrm{~km}^{2}\right)$ and wastelands $\left(0.20 \mathrm{~km}^{2}\right)$. The land use changes led to a reduction in the forest areas from $80.51 \mathrm{~km}^{2}$ in 2001 to $75.70 \mathrm{~km}^{2}$ in 2011, making the total decrease of $4.81 \mathrm{~km}^{2}$, or $5.97 \%$, during the period of 10 years. The decrease in forest area was mainly due to the transformation of $3.34 \mathrm{~km}^{2}$ forest-land into agricultural area and turning of $1.47 \mathrm{~km}^{2}$ of forests into degraded land and wastelands during that period. The degraded land and wasteland within the catchment increased from $2.32 \mathrm{~km}^{2}$ or $2.14 \%$ in 2001 to $2.35 \mathrm{~km}^{2}$ of the total watershed area in 2011 . This increase in wasteland area has been caused by the conversion of a proportion of forests $\left(1.47 \mathrm{~km}^{2}\right)$ into a degraded land. The water-bodies in the headwater recorded a decline of $0.05 \%$ due to a decreased water level of streams and an increased area of dry stream-bed.

The rapid changes in land use and a decline in forest area have disrupted the hydrological regime of Himalayan watershed. Furthermore, during the last 30 years the pattern of Indian monsoon has changed over the Himalayan Mountains resulting in reduction of rainfall and annual rainy days, and an increase in the incidences of erratic rainfall and geo-hydrological disasters in the region (ICIMOD 2010). Studies indicate that the surface run-off from cultivated (80\%) and a barren land (85\%) is much higher compared to that 
from the forests (25\%) (Tiwari 2000). These hydrological disruptions are now clearly discernible in (I) long-term decreasing stream-flow (Tiwari and Joshi 2012a), (II) diminishing discharge and drying of springs (Tiwari and Joshi 2012a), and (III) biotic impact on surface run-off flow system and channel network capacity (Rawat 2009, Tiwari and Joshi 2012a; Tiwari 2000). Table 1 shows that more than 33\% of natural springs have completely dried, nearly $11 \%$ of springs have become seasonal, while the stream-length of $736 \mathrm{~km}$ has dried during the last 30 years mainly due to deforestation and the resultant decreased recharge of groundwater in the region. Table 3 shows that as many as $61 \%$ villages have been facing great scarcity of water for all purposes where the situation turns into severe water crisis during dry months (Tiwari and Joshi 2012a).

Table 1. Changes in the Status of Water Resources in Upper Kosi Catchment

\begin{tabular}{|l|c|c|c|c|}
\hline Micro-watersheds & $\begin{array}{c}\text { Villages facing wa- } \\
\text { ter scarcity (\%) }\end{array}$ & $\begin{array}{c}\text { Decrease in } \\
\text { biomass supply to } \\
\text { agriculture (\%) }\end{array}$ & $\begin{array}{c}\text { Irrigation potential } \\
\text { reduced (\%) }\end{array}$ & $\begin{array}{c}\text { Agricultural pro- } \\
\text { ductivity declined } \\
\text { (\%) }\end{array}$ \\
\hline North Kosi & 67 & 35 & 14 & 25 \\
East Kosi & 51 & 29 & 17 & 33 \\
West Kosi & 69 & 41 & 21 & 19 \\
South Kosi & 57 & 58 & 19 & 24 \\
\hline Total & 61 & 41 & 18 & 25 \\
\hline
\end{tabular}

Source: Field surveys 2011.

The study revealed that availability of water, fuel-wood and fodder decreased while the irrigation potential and agricultural production declined. The depletion of forests and the resultant hydrological disruptions caused 29\% (East Kosi) to 58\% (South Kosi) decline in supply of biomass to agro-ecosystem and loss of 14\% (East Kosi) to 21\% (South Kosi) of irrigation potential (in terms of irrigated area) in different micro-watersheds of Upper Kosi Catchment during last 30 years (Table 2). The loss of primary ecosystem services, particularly, water and biomass has direct adverse impact on the productivity of subsistence agricultural system. The different micro-watersheds of Upper Kosi catchment lost their agricultural productivity ranging from 19\% in West Kosi to 25\% in North Kosi with an overall decline of $25 \%$ (Table 2 ).

Table 2. Changes in Water Availability, Biomass Supply and Irrigation Potential

\begin{tabular}{|l|c|c|c|c|}
\hline Micro-watersheds & Total area $\mathbf{( k m}^{2}$ ) & Springs dried (\%) & $\begin{array}{c}\text { Springs become } \\
\text { seasonal (\%) }\end{array}$ & $\begin{array}{c}\text { Stream-length } \\
\text { dried (m) }\end{array}$ \\
\hline North Kosi & 44.23 & 41 & 17 & 311 \\
East Kosi & 29.18 & 36 & 11 & 227 \\
West Kosi & 23.37 & 47 & 21 & 114 \\
South Kosi & 11.16 & 11 & 05 & 84 \\
\hline Total & 107.94 & 33.75 & 10.80 & 736 \\
\hline
\end{tabular}

Source: Field surveys 2011. 


\section{Impact on Food and Livelihood security}

The region has been facing deficit situations in food, fodder and fuel-wood for long period mainly due to constraints of subsistence economy and population growth. However, the loss of ecosystem services has further increased the resource deficit levels. The region recorded respectively 23-39\%, 13-25\% and 15-37\% deficit of food, fodder and fuel-wood within the different micro-watersheds of the region between 1981 and 2010 (Table 3). A huge proportion of rural population, particularly landless marginalized and poor inhabitants, largely depends on agricultural labour, village based processing of agricultural and livestock products, making agricultural tools and traditional handcraft items and collecting medicinal plants for their livelihood. But due to the depletion of the forests and biodiversity the livelihood based on the forest and medicinal plant collection activities has decreased from $37 \%$ to $40 \%$ and from $20 \%$ to $29 \%$, respectively, in different micro-watersheds. Similarly, livelihood opportunities in agriculture, livestock and handicraft sectors have also declined between $19 \%$ and $29 \%, 9 \%$ and $22 \%$, and $22 \%$ and $40 \%$, respectively, in different micro-watersheds of Upper Kosi Catchment during last 30 years due to a reduced agricultural and livestock productivity (Table 4).

Table 3. Changes in Food, Fodder and Fuel-wood Deficit Situations in Upper Kosi Catchment

\begin{tabular}{|l|c|c|c|}
\hline \multicolumn{1}{|c|}{ Micro-watersheds } & Food deficit (\%) & Fodder deficit (\%) & Fuel-wood deficit (\%) \\
\hline North Kosi & 38 & 19 & 37 \\
East Kosi & 27 & 13 & 15 \\
West Kosi & 39 & 25 & 31 \\
South Kosi & 23 & 24 & 26 \\
\hline Total & 32 & 20 & 27 \\
\hline
\end{tabular}

Source: Field surveys 2011.

Table 4. Impact of Land Use Dynamics on Rural Livelihood in Upper Kosi Catchment

\begin{tabular}{|l|c|c|c|c|c|}
\hline $\begin{array}{c}\text { Micro-wa- } \\
\text { tersheds }\end{array}$ & $\begin{array}{c}\text { Decline in forest } \\
\text { based activities } \\
\text { (\%) }\end{array}$ & $\begin{array}{c}\text { Decline in agro- } \\
\text {-based activities } \\
\text { (\%) }\end{array}$ & $\begin{array}{c}\text { Decline in } \\
\text { medicinal plant } \\
\text { collection activi- } \\
\text { ties (\%) }\end{array}$ & $\begin{array}{c}\text { Decline in } \\
\text { livestock } \\
\text { production } \\
\text { activities (\%) }\end{array}$ & $\begin{array}{c}\text { Decline in tradi- } \\
\text { tional handicraft } \\
\text { \& agricultural } \\
\text { tool making } \\
\text { activities (\%) }\end{array}$ \\
\hline North Kosi & 40 & 24 & 29 & 14 & 26 \\
East Kosi & 34 & 29 & 22 & 15 & 24 \\
West Kosi & 39 & 19 & 23 & 22 & 22 \\
South Kosi & 37 & 24 & 20 & 09 & 40 \\
\hline Total & 38 & 24 & 24 & 15 & 28 \\
\hline
\end{tabular}

Source: Field surveys 2011.

\section{Trends of Rural Out-migration}

During the last 30 years the region has experienced high population growth. The subsistence agricultural economy with high cropping intensity and low productivity has not been able to absorb the increasing population. Consequently, a tendency of out-migration, particularly among the male youths, in search of livelihood and employment has 
been prevailing in the region for a long period of time. The migration is both temporary as well as of permanent nature and includes educated as well as uneducated migrants. However, the depletion of natural resource base, climate change and the resultant loss of ecosystem services; and increasing constraints of livelihood opportunities and food production have accelerated the process of outmigration in the region. Table 5 shows that 21,496 persons have migrated from the region during 2001 and 2010 of which $81.48 \%$ and $18.52 \%$, respectively, were educated and uneducated migrants. Out of the total migrants (21496 persons) during the period $27.79 \%$ migrated permanently whereas as much as $72.21 \%$ migrated on temporary basis (Table 5). The study observed that the trend of outmigration has shown consistently increasing trends during the recent years as the proportion of rural outmigration increased by more than 2966\% during 2001 and 2010 (Table 6).

Table 5. Pattern of Rural Outmigration during 2001-2010

\begin{tabular}{|l|c|c|c|c|c|}
\hline $\begin{array}{c}\text { Micro-water- } \\
\text { sheds }\end{array}$ & Total Migrants & $\begin{array}{c}\text { Permanent } \\
\text { Migrants }\end{array}$ & $\begin{array}{c}\text { Temporary } \\
\text { Migrants }\end{array}$ & $\begin{array}{c}\text { Educated } \\
\text { Migrants }\end{array}$ & $\begin{array}{c}\text { Uneducated } \\
\text { Migrants }\end{array}$ \\
\hline North Kosi & 4076 & 37.00 & 63.00 & 75.21 & 24.79 \\
East Kosi & 4560 & 21.55 & 78.45 & 81.55 & 18.45 \\
West Kosi & 5230 & 37.11 & 62.89 & 77.59 & 22.41 \\
South Kosi & 7630 & 15.51 & 84.49 & 91.57 & 08.43 \\
\hline Total & 21496 & 27.79 & 72.21 & 81.48 & 18.52 \\
\hline
\end{tabular}

Source: Field surveys 2011.

Table 6. Trends of Rural Outmigration during 2001-2010

\begin{tabular}{|l|c|c|}
\hline Years & Total Migrants & Change (\%) \\
\hline 2001 & 701 & - \\
2002 & 795 & 13.41 \\
2003 & 1007 & 26.67 \\
2004 & 1295 & 28.60 \\
2005 & 1491 & 15.13 \\
2006 & 1521 & 02.01 \\
2007 & 1609 & 05.78 \\
2008 & 2975 & 84.90 \\
2009 & 4591 & 54.32 \\
2010 & 5511 & 20.04 \\
\hline Total & 21496 & 2966.48 \\
\hline
\end{tabular}

Source: Field surveys 2011.

\section{Impact on Rural Women}

The depletion of land, water and forest resources has increased the distances to be covered for the collection of primary village resources in the catchment during 2001-2011 (Table 7). The average travel distance involved in the collection of fodder and fuel-wood and fetching water have increased from $0.5 \mathrm{~km}$ to $1.5 \mathrm{~km}$ in different micro-watersheds of 
the catchment during the period. However, the average travel distance for the collection of fuel-wood has increased from $3 \mathrm{~km}$ in 2001 to $3.75 \mathrm{~km}$ in 2011 reflecting the acute pressure on forest resources in the catchment (Table 7). As a result the workload of agricultural and livestock sectors on women has increased (30\%) and the time available for women for personal and child care has reduced (25\%) during 2001-2011. The depletion of water resources has not only stressed the water supply system but also reduced the productivity of traditional agricultural system undermining the community health through a decreasing availability of water for domestic purposes and reducing the quantity as well as quality of food (Tiwari and Joshi 2012b). It was found that 37\% women are not able to take bath on a daily basis due to a reduced availability of water, and out of the remaining $63 \%$ women more than $50 \%$ normally take bath at the water sources and pollute the water resources. The scarcity of potable drinking water is compelling women to fetch water from long distances without taking into account water-quality; in consequence a considerably large proportion of rural population is consuming unsafe drinking water and is affected by several kinds of water-borne diseases. Furthermore, the increased travel distances to collect water have adversely affected the health of women due to an increased workload, less time available for taking care of their hygiene and sanitation on the one hand, while on the other they are not able to take proper health care of their young children and elderly members of family due to lack of time.

It was observed that the reduced availability of water and the resulting poor access to water needed for drinking, sanitation and various other domestic purposes is rendering the population, more particularly the women of the region, highly vulnerable to a variety of water related diseases and health disorders. It was found that a large proportion of women of the catchment are not able to take proper care of their drinking water, sanitation and personal hygiene which is affecting their health conditions. The study revealed that a large proportion of population of all age groups, particularly children and women, are affected by several kinds of water-borne diseases in the region. It was observed that as much as $40 \%$ female population in all age-categories is under severe threat of a variety of health risks generated mainly due unsafe drinking water, unhygienic conditions and lack of sanitation in homes and environs (Table 8). Nearly $69 \%$ of the total population was affected by jaundice, diarrhoea, typhoid, skin infections, dysentery, worm infections, cholera and various other kinds of water borne diseases (Table 8). The percentage of male and female population affected by water-borne diseases ranges between $19 \%$ and $38 \%$ and $31 \%$ and $55 \%$, respectively, in the region (Table 8). In general, women, children below the age of 15 years and the elderly above 55 years have been found to be the most affected by unhygienic conditions and lack of sanitation in the region (Table 8). The girls below the age of 15 suffer the most of water borne health hazards because of less attention to and care of their health due to prevailing gender discrimination in the society.

Furthermore, the decline in food productivity, the recent surge in food prices and a decreased food purchasing power due to economic recession have complicated the health conditions in the region by creating the deficiency of food for a large proportion of population consisting of mainly poor and women households (Tiwari and Joshi 2012b). This has contributed to a reduced supply of vital nutrients to rural population, particularly for the women and children, most of whom are already suffering from malnutrition and nutrients deficiency, affecting the overall community health in the region. Table 9 makes it clear that on an average more than $50 \%$ of the population, including male and female of all age-gro- 
ups, are in the grip of food and nutrition deficiency. The children and aged people of both the sexes are the most affected by food deficiency and malnutrition disorders. However, women of all age-groups have been found much more vulnerable to food deficiency and malnutrition health risk compared to male population in the catchment (Table 9).

Table 7. Distances involved in the Collection of Resources during 2001-2011

\begin{tabular}{|c|c|c|c|c|c|c|}
\hline \multirow{3}{*}{$\begin{array}{l}\text { Micro-wa- } \\
\text { tersheds }\end{array}$} & \multicolumn{6}{|c|}{ Average Travel Distances Involved in Resource Collection (km) } \\
\hline & \multicolumn{2}{|c|}{ Fodder } & \multicolumn{2}{|c|}{ Fuel-wood } & \multicolumn{2}{|c|}{ Water } \\
\hline & 2001 & 2011 & 2001 & 2011 & 2001 & 2011 \\
\hline North Kosi & 2.5 & 3.5 & 2.5 & 3.5 & 0.5 & 1.5 \\
\hline East Kosi & 2.5 & 3.0 & 2.5 & 3.0 & 0.5 & 2.0 \\
\hline West Kosi & 3.0 & 4.0 & 3.0 & 4.0 & 1.0 & 1.5 \\
\hline South Kosi & 3.0 & 4.5 & 4.0 & 4.5 & 0.5 & 1.5 \\
\hline Total & 2.75 & 3.75 & 3.0 & 3.75 & 0.6 & 1.6 \\
\hline
\end{tabular}

Source: Field surveys 2011.

Table 8. Population affected by Different Water Borne Diseases and Sanitation and Hygiene Related Health Problems in 2011

\begin{tabular}{|l|c|c|c|}
\hline \multirow{2}{*}{ Age Category } & \multicolumn{2}{|c|}{$\begin{array}{c}\text { \% of Population affected by Jaundice, Diarrhoea, Typhoid, Skin Infection, Dy- } \\
\text { sentery, Worm Infection, cholera (One and More Diseases) during 2009 2010 }\end{array}$} \\
\cline { 2 - 4 } & Male & Female & \multicolumn{2}{c|}{ Total } \\
\hline Below 5 Years & 19 & 55 & 74 \\
6-15 Years & 28 & 31 & 59 \\
16-40 Years & 25 & 44 & 69 \\
41-55 Years & 35 & 37 & 72 \\
Above 55 Years & 38 & 35 & 73 \\
\hline Total & 29 & 40 & 69 \\
\hline
\end{tabular}

Source: Field surveys 2011.

Table 9. Population affected by Food and Nutrition Deficiency during 2001-2011

\begin{tabular}{|l|c|c|c|}
\hline \multirow{2}{*}{ Age Category } & \multicolumn{2}{|c|}{ Percentage of Population affected by Food and Nutrition Deficiency in 2011 } \\
\cline { 2 - 4 } & Male & Female & Total \\
\hline Below 5 Years & 27 & 36 & 63 \\
$6-15$ Years & 21 & 25 & 46 \\
$16-40$ Years & 11 & 17 & 28 \\
$41-55$ Years & 17 & 29 & 46 \\
Above 55 Years & 38 & 41 & 79 \\
\hline Total & 23 & 30 & 52 \\
\hline
\end{tabular}

Source: Field surveys 2011.

The Himalayas is highly vulnerable to a variety of natural hazards and disasters, such as landslides, cloud bursts, flash floods, avalanches, earthquakes, and forest fires. The process of environmental change and the resultant land use intensifications and hydrolo- 
gical disruptions have increased the susceptibility of these fragile mountains to augmented risks of natural hazards and disasters. Moreover, climate change has contributed to an increased severity, frequency and intensity of extreme weather events, particularly the frequency of high intensity rainfall that can have serious consequences far beyond their mountain sources. An increasing vulnerability to the multiple risks of natural disasters has intensified the trends of rural out-migration in the region (Sherpa 2007). Lessons learned from natural disasters in the Himalayas over the past 20 years illustrate how physiological vulnerabilities, socio-cultural and economic marginalization and gender stereotypes make the differential level of impacts on mountain communities. As a result, the nature and magnitude of the impacts of natural disasters on men and women are totally different during as well as after the disaster (Mehta 2007). The women constitute the highest proportion of population affected by natural disasters primarily due to lack of preparedness and information. The out-migration of male during the post disaster phase, often forces women to shoulder the productive, reproductive and community responsibilities while still suffering from the agony caused by the disaster. Table 10 shows that the number of households affected by extreme weather events and associated natural disasters generally increased, with a few exceptions, during 2001 and 2011 in the catchment. Over the period of 10 years (2001-2011),60\% households on the average were affected by extreme weather events. But it is alarming to observe that the proportion of woman-headed households exceeds 60\% of the total families affected, except in 2010 and 2011, even-though the proportion of woman-headed households is only $27 \%$ (out of total 2197 households) in the catchment. It is also disappointing to note that number of women affected by extreme weather events was growing during the period of 10 years (2001-2011) in the region.

Table 10. Impacts of Extreme Weather Events during 2001-2011

\begin{tabular}{|c|c|c|c|c|}
\hline \multirow{2}{*}{ Years } & \multicolumn{4}{|c|}{ Impacts of Extreme Weather Events During 2001-2011 } \\
\cline { 2 - 5 } & $\begin{array}{c}\text { Total Households } \\
\text { Affected }\end{array}$ & $\begin{array}{c}\text { Women Headed Ho- } \\
\text { useholds Affected }\end{array}$ & $\begin{array}{c}\text { Percentage of } \\
\text { Women-Headed Ho- } \\
\text { useholds Affected }\end{array}$ & $\begin{array}{c}\text { Total Number of } \\
\text { Women Affected }\end{array}$ \\
\hline 2001 & 247 & 151 & 61.13 & 751 \\
2002 & 511 & 345 & 67.50 & 1537 \\
2003 & 531 & 367 & 69.11 & 1527 \\
2004 & 545 & 239 & 43.85 & 1041 \\
2005 & 417 & 265 & 63.54 & 1117 \\
2006 & 677 & 435 & 64.25 & 2137 \\
2007 & 525 & 347 & 60.38 & 1635 \\
2008 & 735 & 469 & 63.81 & 2515 \\
2009 & 755 & 537 & 71.13 & 2738 \\
2010 & 971 & 477 & 49.12 & 2709 \\
2011 & 955 & 475 & 49.74 & 2612 \\
\hline Total & 624 & 374 & 60 & 1847 \\
\hline
\end{tabular}

Source: District Administration Records 2001-2011. 


\section{Conclusion}

In Himalaya, due to the vulnerability of rural communities to water, food, livelihood and health insecurities, but have also increased the susceptibility of mountain communities to multiple risks of natural disasters. These changes have stressed the local production system and increased the trends of out-migration of rural male youths in the region. This has further deteriorated the socio-cultural life of women by increasing their hardships, drudgeries and marginalization in the mountains. As a result the workload of agricultural and livestock sectors on women has increased considerably reducing drastically the time available with them for their personal and child care. The reduced availability of water for food production and decreased access to water for drinking and sanitation are particularly increasing the vulnerability of women to a variety of water-borne and food and nutrition deficiency health risks. Furthermore, the women constitute the highest proportion of population affected by natural disasters primarily due to lack of preparedness and information and more exposure.

Hence, more research is needed to establish best possible strategies for sustainable development in the future, particularly in emerging sectors of rural livelihood in the Himalayas, such as forest conservation, village-based eco-tourism, dairying and horticulture and value chain development. Since the traditional adaptation mechanism and knowledge developed by rural women would play crucial role in ecological restoration and sustainable development of natural resources in view of climate change, gender mainstreaming should form one of the core important components of overall climate change adaptation strategy and sustainable development framework in entire the Himalayas. This underlines the need of empowering rural women in the natural resources for which their educational, social, economic and political empowerment would be inevitable. Moreover, a gender sensitive mountain development agenda and gender inclusive policies would be imperative for attaining the environmental, economic as well as social sustainability in the Himalayas.

\section{References}

Aase H. A., Chapagain P., Tiwari P. C., 2013, Innovation as an Expression of Adaptive Capacity to Change in Himalayan Farming, Mountain Research and Development, Feb. 2013, 33 (1), pp. 4-10, http://dx.doi.org/10.1659/MRD-Journal-D-12-00025.1.

Ashish M., 1983, Agricultural Economy of Kumaon Hills: A threat to Ecological Disaster, [in:] Singh O. P. (ed.), The Himalayas: Nature, Man and Culture, New Delhi, Rajesh Publications, pp. 233-245.

Batliwala S., 2007, Putting Power back into Empowerment, http://www.whenet.org/docs/perspective-srilatha-0707.html

Beniston M., 2005, Mountain climates and climatic change: An overview of processes focusing on the European Alps, Pure and Applied Geophysics, 162, pp. 1587-1606.

Brody A., Demtriades J., Esplen E., 2008, Gender and Climate Change: Mapping the Linkages - A Scoping Study on Knowledge and Gaps, BRIDGE, University of Sussex, Sussex.

CIDA, 2002, Gender Equality and Climate Change: Why consider gender equality when taking action on climate change? Canadian International Development Agency (CIDA), Hull. 
Daley E., 2011, Gendered Impacts of Commercial Pressures on Land, Mokoro, London.

FAO, 2008, Food Security in Mountains - High time for action, Brochure of the International Mountain Day 2008, http://www.mountaineering.ie/documentbank/uploads/IMD08\%20brochure.pdf FAO, 2010, Farmers in a changing climate: does gender matter?, Food and Agricultural Organisation

(FAO), Rome, http://www.fao.org/docrep/013/i1721e/i1721e00.htm

FAO, 2011, The State of Food and Agriculture - Women in Agriculture: Closing the Gender Gap in Development, Food and Agricultural Organisation (FAO), Rome.

Hassan R., Scholes R., Ash N. (eds.), 2005, Ecosystems and human well-being: Current state and trends, vol. 1, Findings of the condition and trends, Working Group of the Millennium Ecosystem Assessment, Washington, Island Press.

Hoermann B., Kollmair M., 2009, Labour migration and remittances in the Hindu Kush-Himalayan region, ICIMOD Working Paper, International Centre for Integrated Mountain Development, Kathmandu, Nepal.

Huddleston B., Ataman E., 2003, Towards a GIS-based analysis of mountain environments and populations, Environment and Natural Resources Working Paper, 10, Food and Agriculture Organization of the United Nations, Rome.

ICIMOD, 1999, Searching for Women's Voices in the Hindu Kush Himalayas, ICIMOD, Kathmandu, Nepal.

ICIMOD, 2010, Gender Perspectives in Mountain Development: New challenges and innovative approaches periodical publication on Sustainable Mountain Development, International Centre for Integrated Mountain Development (ICIMOD), 57, Kathmandu, Nepal.

ICIMOD, 2011, Labour Migration and Remittances in Uttarakhand, Case Study Report, ICIMOD, Kathmandu, Nepal.

IOM, 2008, Migration and climate change, IOM Migration and Research Series, 31, International Organisation for Migration, Geneva.

IFAD, 2001, Rural Poverty: The Challenge of Ending Rural Poverty Report, Oxford University Press.

IPCC, 2007, Climate change 2007: Impacts, adaptation and vulnerability, Working Group II contribution to the Intergovernmental Panel on Climate Change Fourth Assessment Report, Cambridge University Press, Cambridge.

Jain A., Nagarwalla D. J., 2004, Why conserve forests? A baseline study to assess people's perceptions, attitudes and practices for increasing people's involvement in conservation, Dehradun, Appropriate Technology India.

Joshi B., Tiwari P. C., 2013, Women and Sustainable Mountain Development: An illustration of Indigenous Women's Adaptation to Climate Change in Himalayas, paper presented at Sixteenth Sustainable Development Conference - Creating Momentum: Today is Tomorrow, Sustainable Development Policy Institute, Islamabad Pakistan, 10-12 December 2013.

Kollmair M., Manandhar S., Subedi B., Thieme S., 2006, New figures for old stories: Migration and remittance in Nepal, www.migrationletters.com

Lonergan S., 1998, The role of environmental degradation in population displacement, Environmental Change and Security Project Report, 4, pp. 5-15.

Leduc B., Shrestha A., 2008, Gender and Climate Change in the Hindu Kush-Himalayas: Nepal Case Study, International Centre for Integrated Mountain Development (ICIMOD), Kathmandu, Nepal.

Mamgain R. P., 2003, Out-migration among rural households in Uttaranchal: Magnitude and characteristics, Labour and Development (special issue on migration), 9 (2), pp. 259-287.

Maithani B. P., 1996, Towards Sustainable Hill Area Development, Himalayas: Man, Nature and Culture, 16 (2), pp. 4-7. 
Malhotra A., Schuler S. R., 2005, Women's Empowerment as a Variable in International Development in Measuring Empowerment: Cross-Disciplinary Perspectives by Deepa Narayan-Parker, Deepa Narayan, World Bank Publications.

Mehta M., ICIMOD, 2007, Gender and Disasters, Draft Report, International Centre for Integrated Mountain Development (ICIMOD), Kathmandu, Nepal.

Messerli B., Ives J. D. (eds) 1997, Mountains of the world - A global priority, A contribution to Chapter 13 of Agenda 21, Parthenon, New York.

Millennium Ecosystem Assessment, 2005, Ecosystems and Human Well-being: Synthesis, Island Press, Washington, DC.

Nautiyal A., 2003, Women and Development in the Garhwal Himalayas, AJWS, 9, 4, pp. 93-113.

Nellemann C., Verma R., Hislop L. (eds.), 2011, Women at the frontline of climate change: Gender risks and hopes, A Rapid Response Assessment. United Nations Environment Programme, GRID-Arendal.

Pant B. R., 2000, Uttarakhand: A Geographical Introduction, Sharad Nanda, Kumaon Sharadotsav Samiti, Nainital, pp. 9-16.

Rasmussen S. F., Parvez S., 2002, Sustaining Mountain Economies: Sustainable Livelihoods and Poverty Alleviation, Thematic Paper for Bishkek Global Mountain Summit, UNEP (draft).

Rawat J. S., 2009, Saving Himalayan Rivers: developing spring sanctuaries in headwater regions [in:] Shah B. L. (ed.), Natural resource conservation in Uttarakhand, Ankit Prakshan, Haldwani, pp. 41-69.

Sonesson M., Messerli B. (eds.), 2002, The Abisko Agenda: Research for mountain area development, Ambio Special Report, 11, Royal Swedish Academy of Sciences, Stockholm.

Sherpa D., 2007, New Vulnerabilities for Mountain Women: A Different Light on the Greater Himalayas, Final Draft Report, International Centre for Integrated Mountain Development (ICIMOD), Kathmandu, Nepal.

Singh J. S., Pandey U., Tiwari A. K., 1984, Man and Forests: A Central Himalayan Case Study, Ambio, 13, pp. 80-87.

Stromquist N., 2002, Educating as a means for empowering women, [in:] Parpart J. L. Rai Shirin M., Staudt K. (eds.), Rethinking Empowerment, Routledge, London.

Tiwari P. C., 2000, Land Use Changes in Himalayas and their Impact on the Plains Ecosystem: Need for Sustainable Land Use, Land Use Policy, 17, pp. 101-111.

Tiwari P. C., Joshi B., 2012a, Environmental changes and sustainable development of water resources in the Himalayan headwaters of India, International Journal of Water Resource Management, 26 (4), pp. 883-907, DOI 10.1007/ s11269-011-9825-y.

Tiwari P. C., Joshi B., 2012b, Natural and socio-economic factors affecting food security in the Himalayas, Food Security, 4 (2), pp. 195-207, DOI 10.1007/s12571-012-0178-z.

UN, 2012, Outcome of the Conference, Agenda Item - 10. Rio+20: United Nations Conference on Sustainable Development, June 2012, Rio de Janeiro, Brazil.

UNEP, 2004, The fall of water. United Nations Environment Programme, GRID-Arendal, http://www. grida.no/publications/fall-ofthe-water/

UNEP-WCMC, 2002, Mountain Watch: Environmental change and sustainable development in mountains, UNEP, Nairobi, www.unep-wcmc.org/mountains/mountainwatchreport/ (accessed 11 March 2012)

UNDP, 2010, Power, Voice and Rights: A Turning Point for Gender Equality in Asia and the Pacific, Asia Pacific Human Development Report, Colombo, United Nations Development Programme (UNDP) Regional Centre for Asia Pacific. 
Verma R., 2001, Gender, Land and Livelihoods: Through Farmers Eyes, International Development Research Centre (IDRC), Ottawa.

Viviroli D., Weingartner R., Messerli B., 2003, Assessing the Hydrological Significance of the World's Mountains, Mountain Research and Development, 23, pp. 32-40.

World Bank, 2009, India receives world's largest remittance flows, Washington DC, World Bank, http://worldbank.org/E6Y6IE0CQ0 (accessed 14 November 2012)

World Resources Institute, 2005, Millennium Ecosystem Assessment - Ecosystems and Human Well-being: Synthesis, Island Press, Washington, DC. 